\title{
Taking the Road Less Travelled - the Downing Legacy
}

Sharon G. Wolf ${ }^{1 *}$

1. Dept. Chemical Research Support, Weizmann Institute of Science, Rehovot, Israel.

* Corresponding author: sharon.wolf@weizmann.ac.il

This special session honoring Ken's life and work provides an opportunity to reflect on his legacy. I arrived in Ken's lab in 1991 where he had recently demonstrated information beyond $4 \AA$ resolution in TEM images of glucose-embedded tubulin zinc-sheets [1], moving forward from previous intriguing negative stain studies [2,3]. Despite intimidating technical limitations, Ken was certain that the goal of an atomic-resolution tubulin structure was achievable by electron crystallography. Years later, that goal was achieved, guided by Ken's fearless leadership [4]. He taught by example the best things one can learn about the scientific life; deep curiosity, lack of fear to try new things, and simple joy in doing good work.

Ken's list of publications is fascinating (Fig. 1). Besides his huge contribution in tubulin and microtubule structures, Ken was interested in far-ranging subjects ranging from materials sciences to biology, and in technique development. Particularly interesting for me is to find his long-term interest in spectroscopy [57], and his pioneering attempts to reveal chemical content in cryogenically preserved cells [6]. At a Symposium held in Ken's honor in 2014 (Fig. 2) [8], he talked about the privilege of being able to study whatever interested him, and he touched on some of his more unusual projects, including a decelerator for CCD cameras [9], polymer studies for energy applications [7], and more.

I will present previous results $[10,11]$ and new studies of mineral storage deposits in the mitochondria of mammalian and other eukaryotic cells, by cryoSTEM tomography (CSTET) [12, 13] and on-the-spot chemical characterization by EDX. STEM imaging mode allows for quantification of elemental content in intact cells $[14,15]$, and it is fundamental to development of aloof spectroscopy techniques [16, 17], which hold great promise for biological materials. The development of this work, in my mind, is a natural extension of the important lessons learned from my wonderful mentor, Ken Downing.

References:

[1] KH Downing and J Jontes, Journal of Structural Biology 109 (1992), p. 152.

[2] LA Amos and TS Baker, Nature 279 (1979), p. 607.

[3] TA Ceska and SJ Edelstein, J Mol Biol 175 (1984), p. 349.

[4] E Nogales, SG Wolf and KH Downing, Nature 391 (1998), p. 199.

[5] RM Glaeser, KH Downing and BK Jap, Biophysical Journal 59 (1991), p. 934.

[6] LR Comolli, M Kundmann and KH Downing, J Microsc-Oxford 223 (2006), p. 40.

[7] S Yakovlev, NP Balsara and KH Downing, Ultramicroscopy 116 (2012), p. 39.

[8] Scientific Symposium in Honor of Ken Downing, https://www2.lbl.gov/conferences/KD2014/ (2.20.19)

[9] KH Downing and PE Mooney, Rev Sci Instrum 79 (2008), p.

[10] Z Lansky et al., Journal of Structural Biology: X, p. 100002.

[11] SG Wolf et al., Elife 6 (2017), p. e29929.

[12] SG Wolf, L Houben and M Elbaum, Nature Methods 11 (2014), p. 423.

[13] SG Wolf et al. in "Cellular Imaging", ed. E Hanssen, (Springer, Cham), p. 33.

[14] M Elbaum, Advanced Materials 30 (2018), p. 1706681.

[15] SG Wolf, P Rez and M Elbaum, J Microsc 260 (2015), p. 227.

[16] JA Hachtel et al., Science 363 (2019), p. 525.

[17] P Rez et al., Nature Communications 7 (2016), p. 10945. 


\begin{tabular}{|c|c|c|c|c|c|}
\hline & SKA, TA; ZEMLIN, F; BECKMANN, & OF MOLECULAR BIOLOGY & IORHODOPSIN BASED ON HIGH-RESOLUTIC & & 2551 \\
\hline $2+$ & Nogales, E; Wolf, SG; Downing, KH & NATURE & Stucture of the alpha beta tubulin dimer by electron crystallography & 1998 & \\
\hline & Nogales, E; Whittaker, M; Milligan, RA; Downing, KH & CELL & High-resolution model of the microtubule & 1999 & \\
\hline 45 & Grigorieff, N; Ceska, TA; Downing, KH; Baldwin, JM; Henderson, R & JOURNAL OF N & Electron-crrystallographic refinement of the structure of bacteriorhodopsin & 1996 & 812 \\
\hline & Lowe, J; Li, H; Downing, KH; Nogales, E & JOURNAL OF MOLECULAR BIOLOGY & Refined structure of alpha beta-tubulin at $3.5 \mathrm{~A}$ resolution & 2001 & 768 \\
\hline & HENDERSON, R; BALDWIN, JM; DOWNING, KH; LEPAULT, J; ZEMLIN, F & ULTRAMICROSCOPY & STRUCTURE OF PURPLE MEMBRANE FROM HALOBACTERIUM-HALOBIUM - RECORDI & 1986 & \\
\hline 7 & R; Nogales, E; Downing, KH; Zaharevitz, D; Bo & PROCEEDINGS OF TH & phore for epothilone and taxanes: Molecular basis for drug & 200 & \\
\hline & Nogales, E; Downing, KH; Amos, LA; Lowe, J & NATURE STRUCTURAL BIOLOGY & Tubulin and Ftsz form a distinct family of GTPases & 1998 & \\
\hline & Nettles, JH; Li, HL; Cornett, B; Krahn, JM; Snyder, JP; Downing, KH & SCIENCE & The binding mode of epothilone $A$ on alpha, beta-tubulin byelectron crystallogra & a 2004 & \\
\hline $10 \mathrm{~s}$ & Snyder, JP; Nettles, JH; Cornett, B; Downing, KH; Nogales, E & PROCEEDINGS OF THE NATIONAL ACADEMY & The binding conformation of Taxol in beta-tubulin: A model based on electron $\mathrm{Cr}$ & п2001 & 296 \\
\hline 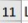 & Li, HL; DeRosier, DJ; Nicholson, WV; Nog & STRUCTURE & Microtubule structure at 8 angstrom Resolution & 2002 & \\
\hline & NOGALES, E; WOLF, SG; KHAN, IA; LUDUENA, RF; DOWNING, KH & NATURE & STRUCTURE OF TUBUULN AT 6.5 ANGSTROM AND LOCATION OF THE TAXOL-BINDING & G1995 & \\
\hline 3 & Downing, KH & DEVELOPMEN & Nstuctural basis for the interaction of tubulin with proteins and drugs that affect & $t 2000$ & \\
\hline & $\mathrm{ng}, \mathrm{KH}$ & & Cryoele & 2001 & \\
\hline $15 \mathrm{r}$ & Henderson, Richard; Sali, Andrej; Baker, Matthew L.; Carragher, B & STRUCTURE & Outcome of the First Electron Microscopy Validation Task Force Meeting & 2012 & 192 \\
\hline 16 & BUTT, HJ; DOWNING, KH; HANSMA, PK & BIOPHYSICAL JOURNAL & IMAGING THE MEMBRANE-PROTEIN BACTERIORHODOPSIN WITH THE ATOMIC FOR & R 1990 & \\
\hline $17 \mathrm{~L}$ & Downing, Kł & IOLOGY & Tubulin and microtubule structure & 1998 & \\
\hline 18 & Bowman, Grant R.; Comolli, Luis R.; Zhu, Jian; Eckart, Michael; Koenig, Marcelle; Dowr & CELL & A polymeric protein anchors the chromosomal origin/Parb complex at a bacteric & ic 2008 & 173 \\
\hline $19 \mathrm{~F}$ & Park, Moon Jeong; Downing, Kenneth H.; Jackson, Andrew; Gomez, Enrique D.; Minor, I & INANO IETTERS & Increased water retention in polymer electrolyte membranes at elevated tempera & a2007 & \\
\hline & & & & 2009 & 137 \\
\hline $21 \mid \mathrm{t}$ & HUD, NV; DOWNING, KH; BALHORN, R & PROCEEDINGS OF THE NATIONAL ACADEMY & A A CONSTANT RADIUS OF CURVATURE MODEL FOR THE ORGANIZATION OF DNA INTC & т1995 & 137 \\
\hline & Downing, KH; Nogales, E & DN IN STRUCTURAL BIOLOG & Tubulin structure: insights into microtubule properties and functions & 1998 & \\
\hline $23+$ & HUD & & IIDEN & N1993 & \\
\hline 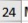 & MCEWEN, BF; DOWNING, KH; GLAESER, RM & ULTRAMICROSCOPY & THE RELEVANCE OF DOSE-FRACTIONATION IN TOMOGRAPHY OF RADIATION-SENSIT & T1995 & 105 \\
\hline 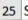 & Sindelar, Charles V.; Downing, Kenneth H. & JOURNALO & The beginning of kinesin's force-generating cycle visualized at 9-A resolution & 2007 & \\
\hline $26 \mathrm{~S}$ & & & o-elect & ct2006 & 100 \\
\hline $27 \mathrm{~s}$ & Sindelar, Charles V.; Downing, Kenneth H. & PROCEEDINGS OF THE NATIONAL ACADEMY & An atomic-level mechanism for activation of the kinesin molecular motors & 2010 & \\
\hline & Facciotti, MT; Rouhani, S; Burkard, FT; Betancourt, FN & BIOPHYSICAL JOURNAL & Stucture of an early intermediate in the M-state phase of the bacteriorhodopsin & & \\
\hline $29 \mathrm{~L}$ & Detrich, HV & LCHEMISTRY & Cold ada & ii 2000 & \\
\hline 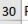 & Richards, KL; $f$ & HE CELL & Structure-function relationships in yeast tubulins & 2000 & \\
\hline $31 \mathrm{~L}$ & Luef, Birgit; Frischkorn, Kyle R.; Wrighton, Kelly C.; Holman, Hoi-Ying N.; Birarda, Giove & EATURE COMN & Diverse uncultivated ultra-small bacterial cells in groundwater & 2015 & \\
\hline $32 \mathrm{~s}$ & & & Structur: & ii 2010 & \\
\hline 33 & DOWNING & SCIENCE & SPOT-SCAN IMAGING IN TRANSMISSION ELECTRON-MICROSCOPY & 1991 & 84 \\
\hline 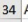 & Amat, Fernando; Moussavi, Farshid; Comolli, Luis R.; Elidan, Gal; Do & CTURAL BIOLOGY & Markov random field based automatic image alignment for electron tomography & v2008 & \\
\hline & Cambie, Rossana; [ & & Design of a microfabrica & e2007 & \\
\hline 20 & & & & t: 2008 & \\
\hline $37 \mathrm{~J}$ & JAP, BK; DOWNING, KH; WALIAN, PJ & CTURAL BIOLOGY & STRUCTURE OF PHOE PORIN IN PROJECTION AT 3.5 A RESOLUTION & 1990 & \\
\hline & GLAESER, RM & & IATION-SENSITIVESP & & \\
\hline $39 \mathrm{~A}$ & Aquil & uics & & 2015 & 62 \\
\hline 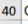 & Como & & Three-din & 2009 & \\
\hline 41 & DOW & & ANALYSI: & & \\
\hline 42 & Bowr & AR MICROBIOLOGY & Ulobacte & 0 & \\
\hline 43 & & & & & \\
\hline & & & Two-c & & \\
\hline 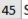 & Shen, $\mathrm{M}$ & JOURNAL O & $n$ of DNAC & 2000 & 57 \\
\hline & & & & 99 & \\
\hline $47 \mathrm{I}$ & Murat, D & Mo & The magnetosome memb & oi 2012 & 52 \\
\hline 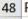 & $\mathrm{S} ; \mathrm{Co}$ & FEBS JOUR & ihationstas of th & c 2006 & 51 \\
\hline & $\mathrm{Ye}$ & & & & \\
\hline & & & & & \\
\hline
\end{tabular}

Figure 1. Ken's 50 most cited papers showing an amazing range of interests and lasting influence.

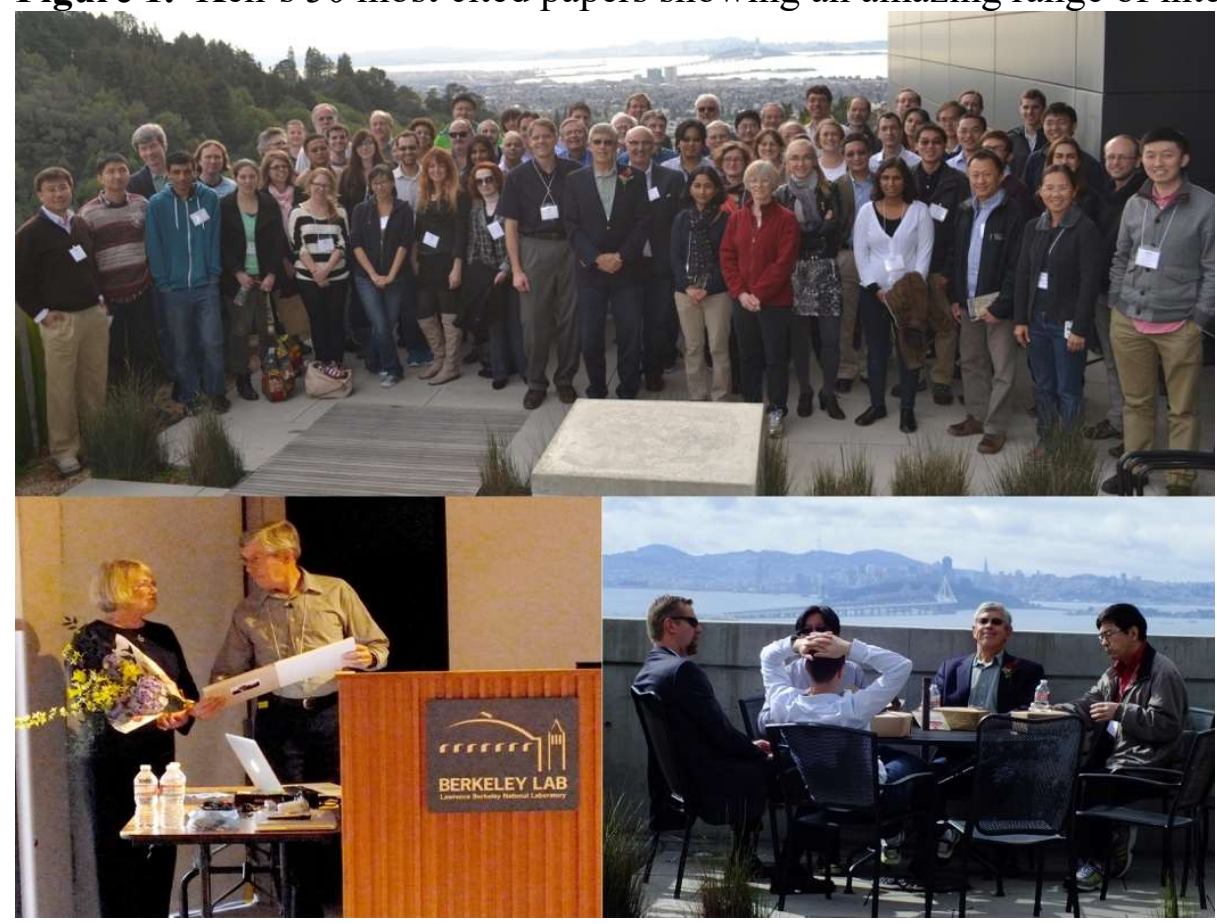

Figure 2. Scientific Symposium celebrating Ken Downing in 2014. 